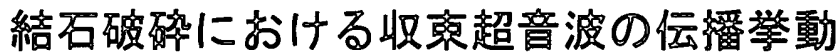

\section{The Behavior of Ultrasound Propagation in Lithotrity}

\author{
○学 池田貞一郎（東大院） 学 吉澤晋（東大院） 正 松本洋一郎（東大工）
}

\begin{abstract}
Teiichiro IKEDA,
Shin YOSHIZAWA

Dept. of Mech. Eng., The Univ. of Tokyo, 7-3-1 Hongo Bunkyo-ku Tokyo 113-8656

Dept. of Mech. Eng., The Univ. of Tokyo, 7-3-1 Hongo Bunkyo-ku Tokyo 113-8656

Yoichiro MATSUMOTO, Dept. of Mech. Eng., The Univ. of Tokyo, 7-3-1 Hongo Bunkyo-ku Tokyo 113-8656
\end{abstract}

\begin{abstract}
In the clinical field, focusing phenomenon of ultrasound is widely applied today, such as Extracorporeal Shock Wave Lithotripsy (ESWL), ultrasonography, and hyperthermia. Although ESWL has been used routinely for the treatment of urolithiasis since 1980's, it also causes acute renal injury by violent collapse of cavitation. To the contrary, the collapse of cavitation by ultrasound focusing can be used for noninvasive lithotrity. It is essential to take a real understanding of the behavior of propagation on ultrasound focusing and the dynamics of cavitation in ultrasound field. To observe focusing phenomenon and cavitation collapse, we made experimental apparatus using piezo-transducer, and numerically simulated the propagation of ultrasound focusing. We observe that ultrasound is plane wave at first, then it gradually takes on nonlinear behavior, and at focus it turns shock wave.
\end{abstract}

Key Words: Ultrasound Focusing, Lithotrity, Numerical Simulation, Cavitation, Piezo Transducer

\section{1. 緢面}

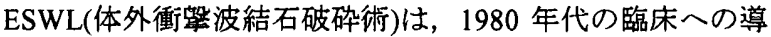
入以来結石破砕の第一選択として定着している. 現在 ESWL においては, 衝拏波ないし超音波収束時のキャビテーション 発生による体組織損傷が問題となっている. しかしながら超 音波を狭い領域に収束させ, キャビテーションによる局所的 な壊食現象 [1]を利用することによって,より矨率のよい低侵 裂結石破砕が可能である。このモデルの実現には収束超音波 の伝播挙動と, 収束超音波音場におけるキャビテーションの 物理現象を解明する必要がある。

\section{2. 收束超音波宾験装圈}

超音波の収束実験および，収束超音波によるキャビテー ション発生実験を行うため, 超音波発生源として球面ピエゾ トランスデューサを用いた実験装直の製作を行った．Fig.1 に示すテストセクション中には水が張られ, 超音波発生装置 として $1[\mathrm{MHz}]$, ないし $500[\mathrm{kHz}]$ の固有振動数を持つ, 焦点 距離 $80[\mathrm{~mm}]$, 開口半径 $40[\mathrm{~mm}]$ の球面ピエゾトランスデュー サが固定されている.

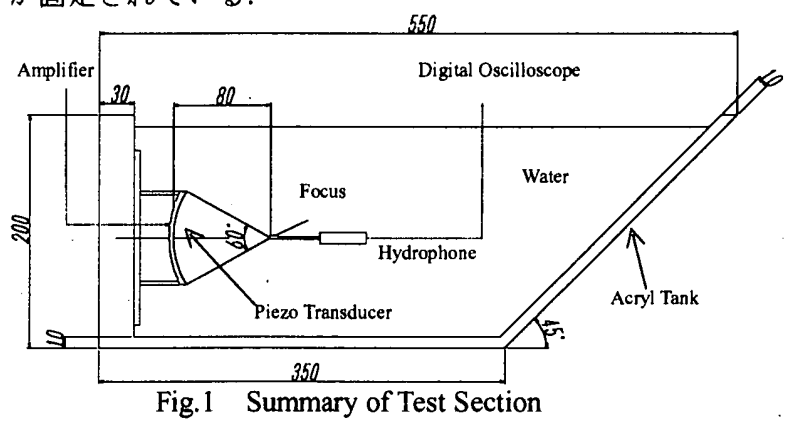

3. 収束超音波伝播シミュレーション

ピエゾトランスデューサによる収束超音波の伝播解析を， 実験装圈をモデル化した数值シミュレーションによって 行った. 支配方程式は二次元軸対称の Euler 方程式，水の状 態方程式としては Tait 式を用い, Harten-Yee の風上 TVD 法 により差分化し解析を行った。境界条件はピエゾ振動面が振 動速度 $V=A \sin 2 \pi f t$ で 2 波バースト振動した時の条件をモデル 化して与えた．振幅は実験装膡から概算した $A=0.07[\mathrm{~m} / \mathrm{s}]$ お よび，その 10 倍の $A=0.7[\mathrm{~m} / \mathrm{s}]$ の 2 通りで与えた.Fig. 2 は振幅 $A=0.07[\mathrm{~m} / \mathrm{s}]$ での，収束超音波伝播の様子である. また, Fig.3,4 は焦点における圧力の時間履歴である.
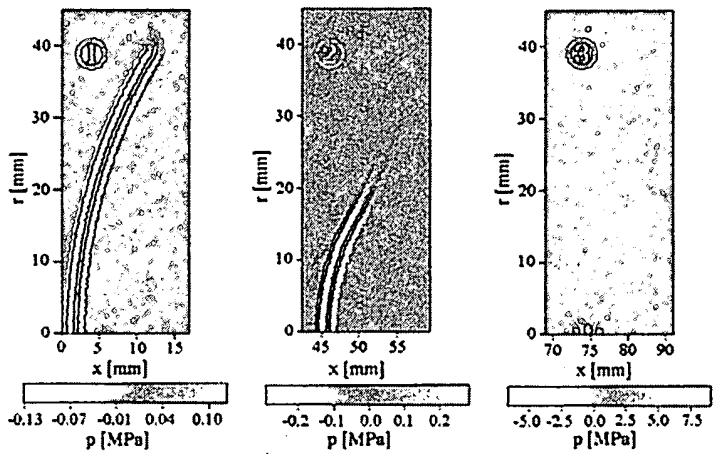

Fig.2 Propagation of Ultrasound $(t=2.0,32.0,55.3[\mu \mathrm{s}])$

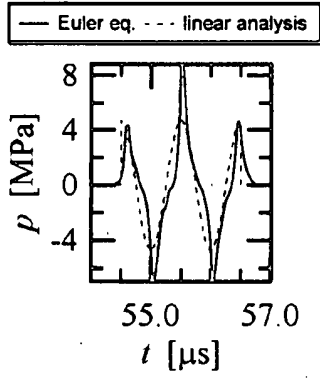

Fig. 3 History of pressure at focus $(A=0.07[\mathrm{~m} / \mathrm{s}])$

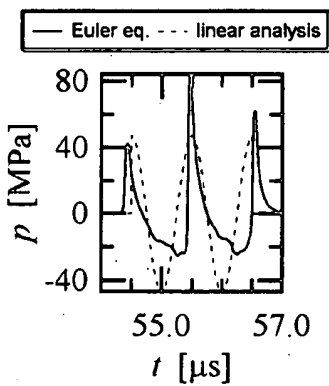

Fig. 4 History of pressure at focus $(A=0.7[\mathrm{~m} / \mathrm{s}])$

\section{4. 結言}

実験装固をモデル化した， Euler 方程式による数值シミュ レーションを行った，その結果を収束超音波の線形波解析と 比較の上考察し, 収束超音波の伝播は以下の 3 ステップから なることを確認した.a)収束過程前半は平面波で超音波は伝 播する，b)収束と同時に次第に圧力が増加し，非線形性を示 し始める.c)焦点近傍において非常に大きな非線形性を示し, 圧力が急激に上昇し, 焦点においては急峻な立ち上がりの高 圧ピークと緩やかな減衰を持つ衝撃波形を形成する。

\section{参考文献}

[1] 島田, 松本ら, “クラウドキャビテーションの動力学と キャビテーションエロージョン”，機論 B 編， 65 巻， 634 号 pp1934-1941, 1996 